\title{
Analisis Korelasi Kemampuan Berpikir Kritis dan Hasil Belajar Mahasiswa Pada Mata Kuliah Fisika Dasar
}

\author{
Ika Daruwati \\ Program Studi Pendidikan Fisika Universitas Pasir Pengaraian \\ Email: ika.dwati@gmail.com
}

\begin{abstract}
ABSTRAK
Penelitian ini bertujuan untuk mengetahui korelasi antara kemampuan berfikir kritis dan hasil belajar fisika dasar mahasiswa fisika semester 2 prodi pendidikan fisika.Penelitian ini mengunakan pendekatan deskriptif kuantitatif. Populasi pada penelitian ini adala mahasiswa fisika dasar semester 2 tahun ajaran 2018/2019. Teknik penggumpulan sampelnya mengunakan teknik sampling jenuh. Instrument penelitian berupa tes dan dokumentasi. Penelitian ini menggunakan analisis regresi dan korelasi.berdasarkan hasil penghitungan data diperoleh dengan menggunakan korelasi didapatkan bahwa $r_{\text {hitung }} 0,991$ sedangkan $r_{\text {tabel }}$ 0,576. Dengan demikian $r_{\text {hitung }}$ lebih besar dari $r_{\text {tabel, }}$ Sehingga dapat disimpulkan bahwa dilihat dari interpretasi koefisien regresi kemampuan berfikir kritis dan hasil belajar fisika mahasiswa mata kuliah fisika dasar berada pada kategori tinggi.
\end{abstract}

Kata Kunci: Korelasi,Kemampuan Berfikir Kritis,Hasil Belajar, Fisika Dasar.

\begin{abstract}
This study aims to determine the ability of critical thinking and the learning outcome of great physisc student a 2 in physics education department. This research uses a descriptive quantitative approach. Population in this study was a great physics students a 2 academic year 2018/2019. Techniques sampling using saturation sampling technique. Research instrumentsin thefrom of tests and documentation. Research using regression anf correlation analysis. Based on data calculation results obtained by using correlation $r_{\text {count }} 0,991$ while $r_{\text {table }} 0,576$. With $r_{\text {count }}$ greater than $r_{\text {table }}\left(r_{\text {count }}\right.$ $>\mathrm{r}_{\text {table)}}$, it can be concluded that from interpretatin viewed of the regression coefficient of critical thinking ability and the result of physics learning of the elementary physics student were in the high category.
\end{abstract}

Keywords: correlation, critical thinking skills, learning outcomes,basic physics.

\section{PENDAHULUAN}

Kurikulum yang dikembangkan pada abad ke 21 dalam pembelajaran telah mengalami pergeseran dari kecenderungan yang menuntut penguasaan konsep siswa saja ke tingkatan yang lebih tinggi. Pembelajaran pada abad 21 telah mengalami perkembangan dimana salah satu keterampilan yang perlu dikuasai adalah berpikir tingkat tinggi seperti berpikir kritis. Beberapa ahli mengartikan berpikir kritis sebagai satu proses berpikir kompleks karena didalamnya terdapat proses berpikir untuk menganalisis argumen dan menghasilkan wawasan ke dalam hal-hal khusus serta melakukan interpetasi. Pendapat tersebut menunjukkan bahwa berpikir kritis menuntun pemikiran yang mendalam terkait pemecahan masalah atau penyelesaian isu-isu tertentu.
Ciri-ciri seseorang mempunyai kemampuan berpikir kritis apabila seseorang dapat mengenal masalah dan menemukan cara-cara yang dapat dipakai untuk menangani masalahmasalah itu, mengumpulkan dan menyusun informasi yang diperlukan, mengenai asumsiasumsi dan nilai-nilai yang tidak dinyatakan, memahami dan menggunakan bahasa yang tepat, jelas, dan khas, menilai fakta dan mengevaluasi pertanyaan-pertanyaan, mengenal adanya hubungan yang logis antara masalahmasalah, menarik kesimpulan yang diambil, dan menyusun kembali pola-pola keyakinan seseorang berdasarkan pengalaman yang luas (Fisher 2009).

Fisika merupakan ilmu pengetahuan yang paling mendasar karena hubungan dengan prilaku dan struktur benda. Salah satu hal penting dalam mendukung pembelajaran fisika 
agar penyampaian konsep lebih yaitu tersedianya sarana dan prasarana yang lengkap (Dewi, 2014).

Salah satu matakuliah dasar yang dapat meningkatkan keterampilan berpikir kritis mahasiswa Universitas Pasir Pangaraian adalah fisika dasar I.

Berdasarkan hasil observasi dan wawancara dengan salah seorang mahasiswa fisika semester 2 pada mata kuliah fisika dasar, mahasiswa masih pasif dan hanya mendengarkan atau mencatat penjelasan dosen, mengerjakan soal-soal yang diberikan, kemudian membawa tugas untuk dikerjakan dan dibahas atau dikumpulkan pada pertemuan selanjutnya. Berdasarkan hasil observasi menunjukkan bahwa matakuliah fisika dasar yang diberikan sebatas penurunan rumus-rumus fisika yang kemudian digunakan untuk mengerjakan soal-soal yang diberikan oleh dosen.

Saat kegiatan pembelajaran berlangsung dan dosen menanyakan apakah ada materi yang tidak dimengerti, mahasiswa cenderung diam dan tidak mengajukan pertanyaan, namun ketika ujian berlangsung mahasiswa merasa kesulitan dalam mengerjakan soal-soal yang diberikan oleh dosen. Kegiatan pembelajaran tersebut membuat mahasiswa terbiasa mengerjakan berbagai tipe soal-soal fisika, namun ketika diberikan permasalahan yang mengarah pada kehidupan sehari-hari, mahasiswa mengalami kesulitan untuk mengaplikasikan teori-teori yang diperoleh dan mengintegrasikan dengan peristiwa-peristiwa dalam kehidupan sehari-hari. Kemampuan mahasiswa untuk mengintegrasikan teori-teori yang dipelajari di kampus dengan peristiwa dalam kehidupan sehari-hari sangat memerlukan keahlian berpikir kritis. Belum terpenuhinya kegiatan pembelajaran yang mengarah pada pengoptimalan kemampuan berpikir kritis mahasiswa dikhawatirkan dapat menyebabkan hasil belajar mahasiswa menurun.

Hasil belajar adalah sejumlah pengalaman yang diperoleh yang mencakup ranah kognitif,afektif, dan psikomotorik. Belajar tidak hanya penguasaan konsep teori mata pelajaran saja, tapi juga penguasaan kebiasaan, persepsi, kesenangan, minat-bakat penyesuaian sosial, macam-macam keterampilan, cita-cita, keinginan dan harapan. Hal tersebut senada dengan pendapat Hamali yang menyatakan bahwa "hasil belajar itu dapat terlihat dari terjadinya perubahan dari persepsi dan perilaku, termasuk perbaikan perilaku menurut (Rusman, 2012).

Seseorang berpikir kritis bila dia dapat mengendalikan masalah yang dihadapinya. Masalah itu dianalisis dalam komponen yang lebih kecil dapat dipecahkannya. Berpikir kritis atau disebut juga dengan berpikir konvergen adalah berfikir reduktif, yakni mereduksi masalah unit-unit yang sekecil-kecilnya lalu menganalisis setiap unit dengan cermat (Nasution, 2012).

Dari latar belakang di atas peneliti tertarik untuk melakukan penelitian berjudul "Analisis Korelasi Kemampuan Berpikir Kritis Dan Hasil Belajar Mahasiswa Pada Mata Kuliah Fisika Dasar".

\section{METODE PENELITIAN}

Jenis penelitian penelitian ini menggunakan korelasional dan pendekatan yang digunakan pendekatan deskriptif kuantitatif. Penelitian ini dilaksanakan di kampus Universitas Pasir Pengaraian Kabupaten Rokan Hulu. Adapun waktu penelitian dilaksanakan pada bulan maret T.A 2017/ 2018. Populasi dari penelitian ini adalah mahasiswa semester 2 prodi pendidkan fisika.Teknik pengambilan sampel menggunakan sampling jenuh yaitu penentuan sampel bila semua anggota populasi digunakan sampel. Sampel dalam penelitian ini adalah mahasiswa fisika semester 2 .

Teknik pengumpulan data pada penelitian ini menggunakan beberapa metode.

\section{Tes}

Menurut (Arikunto, 2010) Tes adalah serentetan pertanyaan atau latihan serta alat lain yang digunakan untuk mengukur keterampilan, pengetahuan, inteligensi, kemampuan atau bakat yang dimiliki oleh individu atau kelompok. 


\section{Metode dokumentasi}

Menurut (riduwan, 2010) Dokumentasi adalah metode yang digunakan untuk memperoleh data langsung dari tempat penelitian, meliputi buku-buku yang relevan, peraturan-peraturan, laporan, kegiatan, fotofoto, film dokumenter,dan penelitian yang relevan

\section{HASIL DAN PEMBAHASAN}

Dari data hasil penelitian yang diperoleh melalui proses penelitian yang dilakukan di kampus Universitas Pasir Pangaraian dengan sampel penelitian mahasiswa fisika semester 2 T.A 2017/2018 yang berjumlah 12 orang. Pengumpulan data yang digunakan peneliti yaitu metode tes. Metode tes berisi pertanyaan tentang materi fisika dasar yang yang terdiri dari 3 sks dan didalamnya terdapat 7 materi sub pokok antara lain besaran dan satuan, besaran vektor dan skalar, kinematika gerak lurus, usaha, energi, hukum kekekalan energi, dan dinamika. Tujuan dari metode tes ini untuk mengetahuan kemampuan berpikir kritis mahasiswa dalam memecahkan soal-soal fisika dasar.

\section{Hasil penelitian}

a. Analisis data dokumentasi hasil nilai fisika dasar dan hasil kemampuan berfikir kritis.

\begin{tabular}{clc}
\multicolumn{3}{c}{ Hasil DataNilai Fisika Dasar 1} \\
\hline & & Nilai \\
No & Kode & Akhir \\
& Mahasiswa & Fisika \\
& & Dasar I \\
\hline 1 & M1 & 60,65 \\
2 & M2 & 60 \\
3 & M3 & 79,75 \\
4 & M4 & 78,5 \\
5 & M5 & 75,63 \\
6 & M6 & 78,15 \\
7 & M7 & 60,65 \\
8 & M8 & 56,7 \\
9 & M9 & 74,8 \\
10 & M10 & 75 \\
11 & M11 & 80,45 \\
12 & M12 & 78,60 \\
\hline \multicolumn{4}{c}{ Jumlah }
\end{tabular}

Nilai Kemampuan Berpikir Kritis

\begin{tabular}{ccc}
\hline No & $\begin{array}{l}\text { Kode } \\
\text { Mahasiswa }\end{array}$ & $\begin{array}{l}\text { Nilai Berfikir } \\
\text { kritis }\end{array}$ \\
\hline 1 & M1 & 80 \\
2 & M2 & 90 \\
3 & M3 & 80 \\
4 & M4 & 85 \\
5 & M5 & 79 \\
6 & M6 & 80 \\
7 & M7 & 81 \\
8 & M8 & 79 \\
9 & M9 & 80 \\
10 & M10 & 83 \\
11 & M11 & 89 \\
12 & M12 & 80 \\
\hline & Jumlah & 986 \\
\hline
\end{tabular}

\section{Grafik hasil belajar fisika}

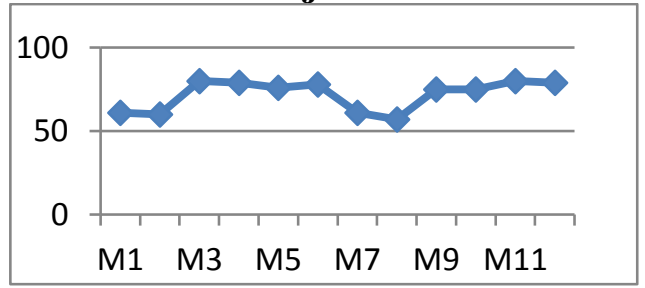

\section{Grafik kemampuanberfikirkritis}

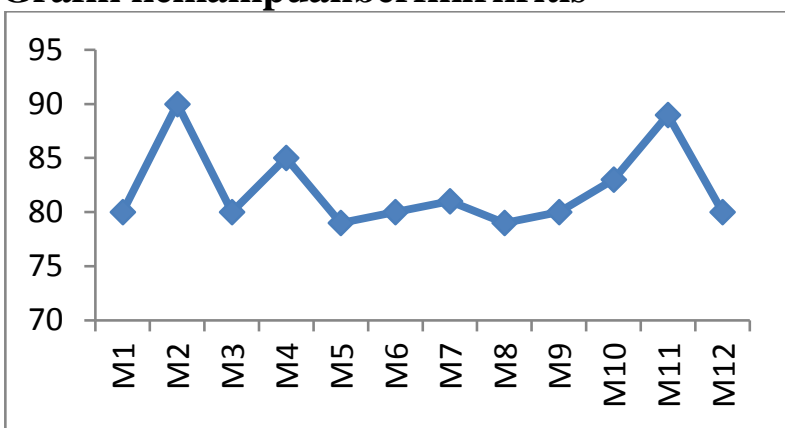

2. korelasi kemampuan berfikir kritis dan hasil belajar fisika

\begin{tabular}{llrrrl}
\hline & $\Sigma \mathrm{X}$ & $\Sigma \mathrm{Y}$ & $\Sigma \mathrm{X}^{2}$ & \multicolumn{1}{c}{$\Sigma \mathrm{Y}^{2}$} & $\Sigma \mathrm{XY}$ \\
\hline Jumla & 98 & 780,2 & 8117 & 62391,5 & 70580, \\
$\mathrm{~h}$ & 6 & 8 & 8 & 7 & 2 \\
\hline
\end{tabular}

Hasil analisis perhitungan data yang dilakukan dengan menggunakan rumus korelasi product moment yaitu 0,9917. Sehingga interpretasi terhadap 12 mahasiswa, diperoleh ( $\left.\mathrm{r}_{\text {tabel }}\right)$ pada taraf signifikasi $5 \%$ sebesar 0,576. Maka telah diketahui nilai $r$ hitung yaitu 0,9917. Dengan demikian $r$ hitung lebih besar dari $r$ tabel $\left(r_{\text {hitung }}>r_{\text {tabel }}\right)$ sehingga dikatakan dalam kategori 
tinggi. Berdasarkan interprestasi terhadap koefisien korelasi tingkat hubungan yang memiliki sangat tinggi.

\section{Analisis Regresi}

$$
\begin{gathered}
\hat{Y}=a+b x \\
Y=3221,9+3.94 x
\end{gathered}
$$

Telah diketahui bahwa $\mathrm{X}$ adalah hasil kemampuan berpikir krtitis dan Y adalah hasil belajar fisika dasar I

Berdasarkan hasil penelitian dan analisis data yang dilakukan peneliti, hubungan antara hasil kemampuan berpikir kritis dan hasil belajar fisika dilihat dengan menggunakan persamaan korelasi Product Moment terhadap 12 mahasiswa semester 2 angkatan 2017/2018 Prodi Pendidikan Fisika, dengan r hitung 0,991. Diperoleh $r$ tabel pada taraf signifikan 5\% sebesar 0,576 sedangkan $\mathrm{r}$ hitung

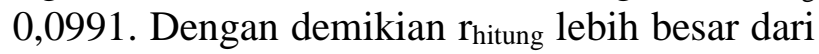
pada $r_{\text {tabel }}\left(r_{\text {hitung }}>r_{\text {tabel }}\right)$. 0leh karena itu, maka korelasi antara kemampuan berpikir kritis dan hasil belajar fisika dasar I berada pada kategori sangat tinggi .

Berdasarkan perhitungan regresi ditemukan harga $a=3221,9$ dan harga $b=3,94$ dengan Persamaan regresi yang digunakan untuk mengetahui hubungan antara kemampuan berpikir kritis dan hasil belajar fisika dasar I adalah $\mathrm{Y}=3221,9+3,94 \mathrm{X}$. Hal ini berarti jika kualitas nilainya ditingkatkan sampai 91, hasil belajarnya menjadi 3580,44 . Sedangkan bila kualitas ditingkatkan lagi dengan penambahan 1 skor dari yang sebelumnya menjadi 92 , maka hasil belajarnya menjadi 3584,38 . Oleh karena itu, dapat simpulkan bila kualitas kemampuan berpikir kritis bertambah 1 maka hasil belajar bertambah 3,94.

Persamaan tersebut mengandung arah koefisien regresi yang berdampak positif, sehingga dapat dikatakan bahwa hasil kemampuan berpikir kritis tinggi. Dengan demikian dapat ditarik kesimpulan bahwa korelasi antara kemampuan berpikir kritis dan hasil belajar fisika dasar memiliki interprestasi sangat tinggi, semakin tinggi kemampuan berpikir kritis mahasiswa dalam memecahkan masalah soal fisika semakin tinggi pula nilai hasil belajar mahasiswa dan bisa dikatakan mahasiswa fisika semester 2 memiliki kemampuan berpikir kritis yang tinggi.

Berpikir kritis merupakan proses mental yang terorganisasi dengan baik dan berperan dalam proses mengambil keputusan untuk memecahkan masalah dan menganalisis dan menginterpretasikan. Berpikir kritis adalah reflektif yang berfokus pada pengambilan keputusan tentang apa yang harus diyakini dan harus dilakukan. Keterampilan berpikir kritis juga dapat dipandang sebagai salah satu modal dasar atau modal intelektual yang sangat penting bagi setiap orang. Oleh karena itu, pengembangan keterampilan berpikir kritis dalam dunia pembelajaran khususnya fisika menjadi sangat penting untuk dikembangkan di sekolah-sekolah pada setiap jenjang pendidikan.

Indikator keterampilan berpikir kritis dari ciri-ciri kemampuan berpikir kritis tersebut dapat diukur ketercapaiannya salah satunya melalui pembelajaran fisika dasar I. Dari aspek proses belajar, melalui pengalaman melakukan pemecahan soal-soal fisika, mahasiswa di didik untuk belajar mengambil kesimpulan dengan berbasis data dan analisis kritis, berpikir rasional, kritis dan mengambil keputusan berdasarkan data yang valid.

Menurut Guilford kemampuan berpikir kritis mengutamakan kekuatan intelegensi dan biasanya diposisikan sebagai kekatan dalam belajar. Kemampuan berpikir kritis meliputi kemampuan kognitif dan watak. Adapun kemampuan kognitif yang menjadi inti dari berpikir kritis yaitu menginterprestasi (interpretation), mengenalisis (analysis), mengevaluasi (evalution), dan menyimpulkan (inference) (Facione, 2007).

Hubungan antara kemampuan berpikir kritis dengan hasil belajar sangat erat kaitannya. Dengan adanya kemampuan berfikir kritis seseorang dapat mengenal masalah dan menemukan cara-cara yang dapat dipakai untuk menangani masalah-masalah itu dan dapat memecahkan soal-soal fisika fisika dasar. 


\section{SIMPULAN}

Berdasarkan hasil penelitian yang dilakukan maka diperoleh kesimpulan bahwa hubungan kemampuan berpikir kritis dan hasil belajar mahasiswa memiliki interpretasi yang sangat tinggi dan mahasiswa fisika semester 2 tahun ajaran 2017/2018 memiliki tingkat kemampuan berpikir kritis yang tinggi. Hal ini dapat dilihat dari tes yang dilakukan untuk mengukur kemampuan berpikir kritis dengan memecahkan soal-soal fisika dasar. Korelasi kemampuan berpikir kritis dengan menggunakan persamaan product moment hasil yang diperoleh adalah bahwa nilai $r_{\text {hitung }}=0.991$ sedangkan $r_{\text {tabel }}$ sebesar 0,576. Dengan demikian $r_{\text {hitung }}$ lebih besar dari pada $r_{\text {tabel }}\left(r_{\text {hitung }}\right.$ $>\mathrm{r}$ tabel) dihubungkan dengan interprestasi koefisien korelasi berada pada kategori sangat tinggi, serta dari persamaan regresi yang diperoleh $\mathrm{Y}=3221,9+3,94 \mathrm{X}$.

\section{SARAN}

Berdasarkan hasil penelitian yang diperoleh, maka ada beberapa hal yang disarankan :

1 Bagi mahasiswa, hendaknya selalu berpikir kritis sehingga mudah untuk memecahkan masalah-masalah disekitar maupun dalam proses belajar mengajar.

2 Bagi peneliti lain, disarankan untuk mengadakan penelitian lebih lanjut sebagai penyempurnaan dalam proses belajar mahasiswa tentang kemampuan berfikir kritis.

\section{DAFTAR PUSTAKA}

Arikunto, S. 2010. Prosedur Penelitian. Jakarta: Rineka Cipta.

Dewi, S. 2014. Efektivitas Alat Peraga Berbasis Teknologi Murah, Sederhana Dalam Pengembangan Fisika. Lampung: UNILA.

Fisher, A. 2009. Berfikir Kritis. Sebuah Pengantar, Bandung: Erlangga.

Nasution, M.A. ,2012. Kurikulum \& Pengajaran. Bandung: Bumi Aksara.

Riduwan, M.B.A 2010. Metode Dan Teknik Menyusun Proposal Penelitian. Bandung :Alfabeta.
Rusman, 2012. Model - Model PembelajaranMengembangkan Profesionalisme Guru. Jakarta: PT rajagrafindo persada. 